\title{
UN POET CATHARTIC ȘI ORACULAR: NICOLAE DABIJA
}

\author{
Florian COPCEA \\ Drobeta Turnu Severin
}

ORCID: https://orcid.org/0000-0002-4914-377X

Rezumat: Nicolae Dabija, promotor asiduu al generației de poeți numită și a ochiului al treilea (critica literară îi atribuie această sintagmă după titlul volumului său de debut - „Ochiul al treilea" (Chișinău, 1975), este considerat un iconograf trăirist și mitic care, ca nimeni altul, în contemporaneitatea noastră imediată a cântat drama pătimirii Basarabiei. El a scris o poezie de factură ,imnică, elegiacă sau monodică, programatic mesianică”, cum observă academicianul Mihai Cimpoi. Poezia sa, datorită valorii ei certe, aflată tot timpul sub semnul identificării sacrificial auctoriale, a fost receptată favorabil, premiată și tradusă într-o mulțime de țări. Poemele lui Nicolae Dabija, inconfundabile și memoriale, nu aparțin numai limbii române din stânga Prutului, ci tuturor celor care sunt dominați de nemărginirea spiritului românesc.

Cuvinte-cheie: poezie, modernism, expresionism, sacralitate, timp, artă poetică.

Abstract: Nicolae Dabija, an assiduous promoter of the generation of poets also called the third eye (literary criticism attributes this phrase to him after the title of his debut volume The Third Eye, Chisinau, 1975), is considered a living and mythical iconographer who, as no one else, in our immediate contemporaneity, sang the drama of the suffering of Bessarabia. He wrote a poem of "hymn, elegiac or monodic, programmatic messianic” nature, as the academician Mihai Cimpoi observes. His poetry, due to its certain value, always under the sign of sacrificial authorial identification, was favorably received, awarded and translated in many countries. Nicolae Dabija's poems, unmistakable and memorial, do not belong only to the Romanian language on the left bank of the Prut, but to all those who are dominated by the boundlessness of the Romanian spirit.

Key-words: poetry, modernism, expressionism, sacredness, time, poetic art.

Poet dezinvolt, cu rezonanță, de o adâncă profunzime po(i)etică, Nicolae Dabija, exponent emblematic al curentului literar numit, poate nu întâmplător, dar în consonanță cu arhetipurile poeziei moderne universale, Ochiul al treilea, caută esența existenței captivat de idealurile și valorile timpului în care trăiește, cu o identitate auctorială indiscutabilă. Poezia sa, solemnizând discursul, dezvoltă elementele unei încifrări ludice ale sensului cuvântului, acesta din urmă pus în împrejurarea de a traversa realitatea cu „lucrurile văzute cu al treilea ochi”, predestinate să viseze „scânteind/ universuri/ de oameni cu aripi/ și pășind pe țărână” (Înger).

În volumul Privighetori împăiate (Ed. Gens Latina, Alba Iulia, 2011), lirismul este expulzat din poem, poezia devenind, cum spunea cândva Ștefan 
Augustin Doinaș, un ordin, o somație adresată realului. Însuși poetul nostru definește poezia ca fiind „un cerc cu centrul în afara sa”, „un cer născocindu-și propria stea", probabil, pentru a ne demonstra că actul poetic este supus limbajului și nu retoricii.

Sentimentul de claustrare, subminat în chip paradoxal de contrastele trăirilor sufletești, generează o imagerie livrească, cu implicaţii expresioniste: „Am deschis cartea/ și casa s-a umplut cu fluturi,/ și iedere au prins să-mi bată în geam.// Am deschis cartea/ și casa mi s-a umplut cu păsări,/ și cu cer nezburat.// Am deschis cartea/ și veșnicia avea miros de flori sălbatice” (Blaga).

Poezia lui Nicolae Dabija este concepută ca un ritual în care „nevindecate de poezie,/ îmbolnăviți de veșnicie” (Memoriu) ne regăsim ființa (deseori rătăcită prin labirintul istoriei) și dăm un sens realității, eventual, după cum decretase T.S. Elliot, un fel de măsură a lucrurilor. Convingerea lui Nicolae Dabija este că logosul (aici în sens de întrupare a inteligenței) îi potențează și-i penetrează organic propriul său discurs. Sacralitatea acestuia este obsesiv susținută de un dolorism visceral. Descoperim în poemul (care dă și titlul volumului) Privighetori împăiate, o senzorialitate și o filosofare alchimică ce nu exclude exuberanța, dar îi dematerializează sentimentele: „Și mi se face cald de-atâta frig./ Și trist devin - de-atâta bucurie./ Mi-aud tăcerea doar atunci când strig./ Sau când poema singură se scrie// [...]// În căutarea sensului, cel greu,/ Poemul-1 șlefuiesc, până se strică.../ De-atâta bine mi se face rău,/ și de atât curaj, Doamne, mi-i frică" (Sipica).

Întreaga structură poetică a lui Nicolae Dabija, adept al extincției oraculare, reproiectează discursul catilinar al unei generații de poeți refractară la modernism, dezorientată de particularitățile impuse de noul estetism, care presupune, aflăm de la Mihai Cimpoi, un mixaj al realismului cu irealismul. Universul poetului nostru, soteriologic și escatologic, este caracterizat de mitul jocurilor poetice, de o antimetafizică aproape mistică a stărilor edenice: „Vroiam să dobor secunda cu o săgeată./ Vroiam să măsor cu o iubire vecia./ Mult prea multă-mi părea Poezia/ Și-a mea îmi era lumea toată.../ [...]/ Mult prea multă-mi părea Poezia/ Vroiam să măsor cu o iubire vecia./ Vroiam să dobor secunda cu o săgeată” (Clepsidra).

Substanța poeziei este topită într-un barochism care ne obligă să înțelegem că „locuirea poetică a lumii” (Holderlin) face parte din spectacolul unor inițieri în ebuliţie, susținut încrâncenat atât de un lirism ludic, organicist-epistemologic, cât și de simboluri ancestrale care, orice am spune, resuscită întotdeauna, testamentar, relativitatea senzitivă a cuvintelor, singurele căi de pătrundere în 
adâncimile Ființei: „Eu fotografiez fulgere/ despicând bezne,/ ceruri/ sau brazi/ [...]/ lângă arborii bătrâni și însingurați/ le momesc/ periculoasă profesie,/ aproape la fel de periculoasă/ ca viața însăși -/ să fotografiezi fulgere.// [...]/ vă las ca amintire/ acest fulger/ care am/ fost” (Fotograful de fulgere).

Tema timpului străbate fiecare poem al acestui omogen volum în care poetul, resemnat, pare să-și „împăieze” amintirile și să ni le lase, totuși vii, într-o vitrină cosmică. Desigur, în acest spațiu despărțit de lumea reală cu un zid de sticlă, s-au cuibărit „poezii nezise” și neantul existențial: „Să scrii un poem în care cuvintele/ să se nască unele din altele,/ așa cum se naște - un ecou/ din ecoul/ altui ecou,/ încât acel care moare -/ ascultându-l,/ să aibă impresia că se naște din nou” (Acel care moare...) sau „... dincolo mă așteaptă viața mea/ netrăită/ și cămășile uitate pe sârmă...” (Câmp minat) și: „...numai umerii mă dor/ în locul unde aripile/ urmau să răsară." (Fără titlu).

Deșertăciunea vieții forează adânc, la infinit, în tristețea cosmică a poemului, anxietatea fiind estompată de „holograme” care reconstituie absolutul: „Poetul.../ [...]/ spune cuvinte ce declanșează fulgere/ și ploaia la vremuri/ de secetă.// [...]/ El care plătește cu propria viață/ dreptul la iluzie” (Dreptul la iluzie) și: „Din când în când/ m-ascund de moarte/ în câte-un vers, în câte-un rând..." (Din când în când). Poemul Sunt singur, contaminat de neliniști clar-obscure, metafizice, este o inserție filosofică de inspirație argheziană: „Sunt singur,/ ca o ploaie/ pe care o așteaptă caișii,/ [...]/ singur,/ singur,/ singur,/ ca un aed uitat de cuvinte/ la marginea unui poem,/ unde timpul e epic,/ iar răspunsul venit atât de târziu/ și-a uitat demult întrebarea" (Sunt singur).

Privighetori împăiate este chintesența operei poetice a lui Nicolae Dabija, construcțiile sale prozodice exprimând, simptomatic, crezul unui poet cathartic care a adus „dulcelui stil clasic” matricial elementele unui limbaj modern, bogat în sensuri caleidoscopice și în fulgerații de spirit. S-au încercat $n$ definiri ale poeziei lui Nicolae Dabija. Unii i-au căutat geneza în autohtonism/ tradiționalism/ clasicism, alții în arhetipurile eminesciene. Puțini însă au sesizat (printre aceștia aflându-se Mihai Cimpoi și Alexandru Burlacu) că Nicolae Dabija, deși este un „spirit al veacului”, militant și iisusic, respinge prin scrierile sale aceste postulate și aduce în literatura basarabeană înnoitoarele paradigme poetice universale. Raportarea sa la vechile modele conservatoare ar fi o greșeală. $\mathrm{Nu}$ vom nega influențele rizomatice ale poeziei antireformiștilor asupra eului său poetic, dar este un fapt că Nicolae Dabija a contribuit, prin experiențele sale lirice, la consolidarea în spațiul din stânga Prutului a valorilor poeticii europene, a promovării unei noi direcții în poezia românească. În concluzie, 
limbajul poeziilor lui Nicolae Dabija, dublat de originalitate și organicitate, incontestabile, se face remarcat prin mesaj și ideal estetic. Iată o convingătoare artă poetică din Doruri interzise (Ed. Litera Internațional, 2004) care ne-a sprijinit în demersul nostru de a demonstra că Nicolae Dabija poate fi plasat, fără riscuri, în galeria marilor poeți europeni: „Poema se scrie pe sine/ sub ochii înmărmuriţi ai poetului/ care mai crede-n istorisirile măslinului/ când vântul își încâlcește/ poveștile-n ramurile lui.// Și doar cerneala de pe mâini,/ precum sângele care pătează palmele/ asasinului/ adeveri-va cu mult mai târziu/ de evenimentul pe care a doua zi-1/ vor consemna toate ziarele" (Poema).

\section{Referințe bibliografice:}

1 CIMPOI, Mihai. O istorie deschisă a literaturii române din Basarabia. Chișinău: Editura ARC, 1997.

2 CIOCANU, Ion. Literatura română contemporană din Republica Moldova. Chișinău: Litera, 1998.

3 COPCEA, Florian. Critice. Oglinzile lui Sisif. Craiova: Grafix, 2018.

4 DABIJA, Nicolae. Doruri interzise. Chișinău: Litera Internațional, 2004.

5 DABIJA, Nicolae. Ochiul al treilea. Chișinău: Cartea Moldovenească, 1975.

6 DABIJA, Nicolae. Privighetori împăiate. Alba Iulia: Ed. Gens Latina, 2011. 